\title{
IMPACTS OF NEOLIBERALISM ON HOSPITAL NURSING WORK
}

\author{
Francisco Gleidson de Azevedo Gonçalves", Norma Valéria Dantas de Oliveira Souza², Regina Célia Gollner \\ Zeitoune $^{3}$, Gabriela Fontes Pessanha Leite Adame ${ }^{4}$, Sonia Maria Pereira do Nascimento ${ }^{5}$
}

${ }^{1}$ M.Sc. in Nursing. Substitute Professor, Departamento de Enfermagem Médico-Cirúrgica, Faculdade de Enfermagem (ENF) at Universidade do Estado do Rio de Janeiro (UERJ). Rio de Janeiro, Rio de Janeiro, Brazil. E-mail: gleydy_fran@hotmail.com

${ }^{2}$ Ph.D. in Nursing. Adjunct Professor, Departamento de Enfermagem Médico-Cirúrgica at ENF/UERJ. Rio de Janeiro, Rio de Janeiro, Brazil. E-mail: norval_souza@yahoo.com.br

${ }^{3}$ Ph.D. in Nursing. Full Professor, Departamento de Enfermagem de Saúde Pública, Escola de Enfermagem Anna Nery, Universidade Federal do Rio de Janeiro. Rio de Janeiro, Rio de Janeiro, Brazil. E-mail: regina.zeitoune@gmail.com

${ }^{4}$ Nurse Specialist in Medical-Surgical Nursing and Trauma, Orthopedics, Instituto Nacional de Traumatologia e Ortopedia. Rio de Janeiro Rio de Janeiro, Brazil. E-mail: gabrifpl@hotmail.com

${ }^{5}$ Nurse. Rio de Janeiro, Rio de Janeiro, Brazil. E-mail: soniarj@ig.com.br

\begin{abstract}
This study aims to describe and analyze the implications of the neoliberal model in the dynamics of hospital work, in the view of the nursing workers. It is a qualitative, descriptive and exploratory research. The scenario is a teaching hospital, and the subjects are 17 nursing workers. The collection took place in July and August 2011, through a semi-structured interview. The data treatment technique was the content analysis. The results show that neoliberalism in hospital nursing work entails several negative impacts, which focus on the inappropriate distribution of material resources, as well as the heavy use of technologies in the process of care. There is also a high turnover of workers contracted due to low wages and precarious employment conditions. We conclude that the neoliberal model has both negative and positive effects. It is considered important to approach this subject in training courses of future nursing staff.
\end{abstract}

DESCRIPTORS: Nursing. Working conditions. Occupational health.

\section{IMPACTOS DO NEOLIBERALISMO NO TRABALHO HOSPITALAR DE ENFERMAGEM}

RESUMO: O presente estudo objetiva descrever e analisar as implicações do modelo neoliberal na dinâmica do trabalho hospitalar, na visão dos trabalhadores de enfermagem. Trata-se de uma pesquisa qualitativa, descritiva e exploratória. O cenário é um hospital universitário e os sujeitos são 17 trabalhadores de enfermagem. A coleta aconteceu em julho e agosto de 2011, por meio de entrevista semiestruturada. A técnica de tratamento dos dados foi a análise de conteúdo. Os resultados evidenciam que o neoliberalismo no trabalho hospitalar de enfermagem traz diversos impactos negativos, que incidem sobre a inadequada distribuição dos recursos materiais, assim como o uso intenso de tecnologias no processo de cuidar. Constata-se também uma alta rotatividade de trabalhadores contratados devido aos baixos salários e às precarização das condições laborais. Conclui-se que o modelo neoliberal tem repercussões tanto negativas quanto positivas. Considera-se importante a abordagem dessa temática em cursos formadores dos futuros trabalhadores de enfermagem.

DESCRITORES: Enfermagem. Condições de trabalho. Saúde do trabalhador.

\section{IMPACTOS DEL NEOLIBERALISMO EN EL TRABAJO HOSPITALAR DE ENFERMERÍA}

RESUMEN: Estudio pretende describir y analizar las consecuencias del modelo neoliberal en la dinámica de trabajo hospital, en vista de trabajadores de enfermería. Investigación cualitativa, descriptiva y exploratoria. El escenario es un hospital de enseñanza, y los temas son 17 trabajadores de enfermería. Colección tuvo lugar en julio y agosto de 2011, a través de entrevistas semi-estructuradas. Técnica de tratamiento de datos fue análisis de contenido. Resultados muestran que el neoliberalismo en el trabajo hospitalario de enfermería trae varios impactos negativos, que se centran en la distribución inadecuada de los recursos materiales, así como el uso intensivo de tecnologías en el proceso de atención. También hay una alta rotación de trabajadores contratados debido a los bajos salarios y condiciones de empleo precario. Llegamos la conclusión de que el modelo neoliberal tiene efectos tanto negativos como positivos. Se considera importante abordar este tema en el futuro cursos formadores del personal de enfermería.

DESCRIPTORES: Enfermería. Condiciones de trabajo. Salud laboral. 


\section{INTRODUCTION}

Work is one of the most important elements of people's insertion in social life, due to its central place in the contemporary world; therefore, it has been a fundamental factor in the construction and reconstruction of people's subjectivity, social status and material subsistence. In that sense, work is a relevant influence in the health-disease process of the group. ${ }^{1}$

The work relations and conditions have undergone countless transformations after the consolidation of the flexible accumulation process, based on the neoliberal precepts and triggered in the 1990's. Thus, the search for the maximization of profits produced a new form of exploitation and control of the workforce, leading to the deregulation of social and occupational rights, reducing the number of employees; increasing the outsourcing and subproletarianization, encouraging precarious and partial work and expanding structural unemployment. $^{2}$

As a result of these transformations, the reality of work is characterized by the increase in the work rhythm, the increase of temporary work, individualism, enhanced competitiveness among workers, search for fierce and uninterrupted training of selected groups of workers, polyvalence and multiple functions of the workers who remain in the job market, among other changes. The reduction of workforce costs and the increase of labor taxes and low wages also reflect these changes. ${ }^{3}$

These transformations also lead to reflections in the health sector and in nursing work. In this sense, the increasing growth of underemployment is observed, with workers associated in cooperatives and outsourced, receiving lower wages than professionals working on a fixed contract and those formally hired under the Consolidation of Labor Laws (CLT), which impels them to multiple employment bond; in addition, it motivates them to take part in precarious work conditions and relations, based on neoliberalism. ${ }^{4}$

Neoliberalism finds its origin in liberal thinking and can be defined preliminarily as the economic policy of indiscriminate opening of the national to the international market. ${ }^{5}$ Nevertheless, neoliberalism is not an economic doctrine, but also a social philosophy and one of social values, which radically transformed life in society and the work relations.
As a result of all of these transformations in the job world, the Brazilian State assumes more liberal traits in terms of the deregulation of work and wellbeing, leading to increasing insecurity in the work relations in different sectors, including health. ${ }^{6}$

That is the job context for nursing workers, i.e. nurses, nursing technicians and auxiliary nurses. The nurses are professionals with a higher education degree who manage the nursing services, plan and assess the care delivery, mostly executed by technicians and auxiliaries, each of whom has specific responsibilities. All of these workers are influenced by the changes that happen in society, specifically in the job world.

From that perspective, the intense increase in the nursing work process can be mentioned, in the use of technology, which in turn modifies the operation mode of the category, increasing the pressure towards training, productiveness and excellent performance. On the other hand, the expansion in the devaluation of work is found, with increased unemployment, intensification of precarious work and the adoption of hired and/ or outsourced nursing workers. ${ }^{7-8}$

This study is justified because, in a literature review about the theme in the main databases of the Virtual Health Library (VHL), little scientific production is observed about the direct relation between the neoliberal model and nursing work. In addition, this model has resulted in countless transformations for nursing work, for the organization and the work process of this professional category as well as for the conditions this work takes place in. In that sense, reflection and knowledge production are due on this relatively new phenomenon for nursing, thus creating conditions to elaborate strategies to protect workers' health and promote a better quality of life.

This study contributes through the understanding that hospital and specifically nursing work has been strongly influenced by the neoliberal and globalized policy, leading to the precariousness of the work conditions and relations; harmful results for this context and for the quality of care delivery. Thus, the professionals can better understand the process they are going through and get equipped to claim better work and health conditions.

In view of this problem, the interferences of the neoliberal model for hospital nursing work 
were selected as the research problem, according to workers from this professional group. The objectives outlined were to describe and analyze the implications of the neoliberal model in the dynamics of the neoliberal model for hospital nursing work according to nursing workers.

\section{METHOD}

This is a descriptive and exploratory research with a qualitative approach; the scenario was a large public university hospital located in Rio de Janeiro-RJ, Brazil.

The research subjects were 17 nursing workers, including seven nurses and ten nursing technicians. The criteria to select these subjects were: being a clinical nursing professionals who worked at the institution and who was active, i.e. not on vacation or leave; working under a fixed job contract; having worked at the institution before or since the 1990's, a period marked by intense transformations in the job world, due to the transition from the Taylorist/ Fordist production model to the neoliberal.

The criteria on the subjects working on a fixed contract rests on the fact that the workers hired on other contracts remain at the hospital for five years at most and, therefore, did not experience the socioeconomic transformations in that workplace.

The data were collected in July and August 2011, specifically at the following sectors: Medical Clinic, Ophthalmology Clinic, Nephrology clinic, Cardiac Intensive Care Center, Service for Infectious and Parasitic Diseases, Hemodialysis Clinic, Neurology Clinic, Coronary Unit, General Surgery and Nutritional Support Clinic.

The choice of these scenarios is due to the fact that those were the places where nursing team workers were present who complied with the profile for inclusion in the study. In addition, the authors were already familiar with the organization and the work process, as well as with many of the managers, which facilitated the insertion in the scenario to develop the research.

The data collection tool was the semistructured interview, applied through questions that allowed the nursing professionals to discuss the main repercussions of neoliberalism for hospital nursing work. The testimonies were recorded on a multimedia player and fully transcribed for further analysis.
Before the data collection, a pretest was applied to four nursing team professionals, two nurses and two nursing technicians, in order to verify whether the tool was appropriate to the research objectives and was easy to understand for the possible subjects. Based on that pretest, small adjustments could be made in the formulation of the questions in the interview script. The professionals interviewed in this pretest phase were not included in the total number of subjects, but were excluded from the final number.

The data treatment technique was thematic content analysis, considered as the organization of information collected through phases or steps, leading to a structured and organized result of the content. The content analysis is a process through which the empirical material is carefully and systematically transformed and coded in units that permit an exact description of the characteristics of the contents in the discourse analyzed. ${ }^{9}$

In the presentation of the results, the subjects were identified using the figures corresponding to the interviews; hence, the first interviewee received code E1 and so forth. Thus, the subjects' anonymity was guaranteed as established in Resolution 196/96 about research involving human beings.

In compliance with that Resolution, the project was submitted to and received Institutional Review Board approval at the institution where the research was undertaken, under protocol 2.966/2011.

\section{RESULTS AND DISCUSSION}

After applying the method, 218 registration units (RUs) emerged, which were grouped in four thematic categories, as follows: management of the hospital service in line with the neoliberal model; health care technologies; interpersonal relationship difficulties; and implications of the neoliberal model in socioeconomic health policies.

\section{Management of hospital services in line with the neoliberal model}

This first category corresponded to 78 RUs, equivalent to $35.77 \%$ of all RUs in the categories. This category includes the contents representative of the hospital management when the subjects mention an improvement in the distribution of 
the material resources, due to the heads' greater control of the storage, liberation and use of the materials, minimizing waste and losses.

The interviewees also highlight the creation of the material central as an important administrative device that helps to control the distribution of material resources to the care services, through the reception of daily, weekly or monthly requests. They equally highlight the implementation of the Standard Operating Procedures (SOP) as a relevant tool to guarantee a rational distribution of resources.

Because the material was not centralized formerly. You had to ask it before. You went to the storage room and took it. Now there is a materials central that distributes 24 hours. You're not left without material. But they don't simply give it to you either. You used to ask for 50 boxes of gauze and they sent 50 boxes of gauze. Now you ask for it and it does not come. The control is much higher and more technical [...] (E10).

They're doing a course on Standard Operating Procedures lately, a course on hospital infection, a course on catheter handling, several courses. The SOPs are the Standard Operating Programs. They are going to implement these SOPs, so it will get more systemized and the control will be more scientific [...] (E5).

The subjects' discourse reveals the institution's greater control over spending on materials. This shows that one of the measures the management found to control the materials is the implementation of the SOPs, which not only provides for care systemization, but also results in less spending on material and less waste.

In that sense, some authors perceive that the SOP offers the benefit of greater consumption control to the institution, saves time for the nursing team and demands less psychophysical effort from the workers. In addition, it unifies and updates techniques, clarifies doubts and avoids errors, granting greater security to the client and employee, and permits the correct accomplishment of procedures, contributing to high-quality nursing care. ${ }^{10-11}$

As a result of the application of some management techniques, such as the implementation of the SOPs, nursing adopts yet another strategy to guarantee the quality of care and improve the nursing care management, with a view to reaching not only an acceptable care standard, but also to attend to the expectations of workers and patients and the work organization, minimizing spending and enhancing profits through increased productivity. ${ }^{10}$

\section{Health care technologies}

The second category consisted of 51 RUs ( $23.39 \%$ of the total). In this category, the changes the subjects perceived after the advent of the neoliberal model stand out, in which the intense use of technologies in the work process results in a greater availability of time to take care of the client, as the equipment employed in care provides parameters of vital signs, read the clients' clinical conditions, among other aspects that facilitate the work process and contribute to qualify the care provided to the clients. These data can be revealed in the following excerpt:

[...] and, going back to the time when I started, there was no infusion pump, technology, you used micro-drips, a watch, and you counted to put 15 micro-drips per minute [...], what got better in terms of material resources were the monitors, ventilators, which undoubtedly reduces the nursing work. Today everything is online, you see invasive pressure, noninvasive pressure, PIC pressure, all of that reduces the errors and work [...] (E6).

Based on this report, it is verified that, at the same time as the greater use of technology helps to optimize the professional's time, it equally contributes to a safer and therefore higher-quality care.

In addition, it is acknowledged that the technology is a fundamental tool to be used to prevent errors and, consequently, in the safety of care delivery to hospitalized patients ${ }^{12}$. It is also inferred that the technology can add positive aspects to occupational health, as it reduces transportation, reduces the professional's time and energy spent, lowers the work rhythm, therefore contributing to the health of the nursing staff. ${ }^{13}$

Nevertheless, the subjects underline that the excessive use of technology can disqualify the care delivery, as the professional no longer needs to stay at the bedside constantly, causing a distancing from the work object: care for the human being. This can be verified in the following statements, evidencing the subjects' concern with their distancing from direct contact with the clients, who can no longer express their feelings to the nurses and, in turn, these professionals are unable to identify the clients' holistic needs. 
It's, I think that, for example, this prescription now you do it on-line, it has gotten easier for everyone, for the pharmacy staff, for us, but this kind of distances the professionals from the patients [...] (E05).

I see that this often makes the nursing professional get seduced by the equipment, and forget about the individual, who is the person he was prepared to take care of, at risk of dehumanizing the nursing care [...] (E09).

In our midst, greater concern with the excessive use is observed for the establishment of relations among the human beings, excessively through machines and equipment, which impairs the social relations. ${ }^{14}$

A study on the social representations of nursing care on the use of technologies identifies that, in the delivery of care based on the information produced through the use of machines, there is a distancing between the professional and the client, as the latter is unable to communicate all of his basic needs to the nurse, who in turn do not attend to the patient holistically, resulting in an action that does not represent care. ${ }^{15}$

In this context, it is important to highlight the different positions towards the use of technology and nursing care, highlighting that technology does not replace the human capacity to deliver comprehensive and personalized care, like in the case of a smile, a touch, a kind look, which humanize the care. ${ }^{14}$

In addition, the incorporation of technological advances in client care is another contradictory and sometimes perverse aspect for the workers, as they need to be constantly available for learning and training on how to manage the technological apparatus, as the introduction of technologies in the health service is massive and daily, showing that the workers have hardly learned the functioning and resources of a given technology when another more powerful and advanced technology is introduced, making the professionals abandon what they were learning to restart the learning process. This situation is frequent, evidencing the constant use of the workers' special cognitive aspects, resulting in psychosomatic wear. ${ }^{13-14}$

\section{Interpersonal relationship difficulty}

In the third category, the unstable employment bonds and the high turnover of hired nursing workers are registered, who resign from their job contract at the hospital due to better wage proposals. This fact wears out the permanent professionals, as they need to constantly train the workers who replace the professionals who left. This situation turns into a vicious circle, in which professionals enter and leave this employment context, and the permanent staff uninterruptedly trains workers with precarious job contracts.

These precarious job contracts entail another deployment: the wage difference, which the subjects report on as a factor that influences the interpersonal relationships, causing conflicts and tension among the permanent and non-permanent staff. The precariousness of the job conditions is a characteristic of the neoliberal model, deteriorating the interpersonal relation, the labor rights and the stability at work, which in turn causes competitiveness, which will give rise to new interpersonal conflicts. ${ }^{4}$ The following statements exemplify these situations:

[...] to the extent that he gets trained, other opportunities arise in the job market and this worker leaves. So the turnover is very high. Because they change very frequently. Sometimes they stay two, three months and leave. And that is a disaster for a specialized service. So this precariousness of work is a thing that strongly marks the work here at the hospital and affects the quality of the care we offer [...] (E14).

I see there is a turnover that comes with low quality and a complex demand, according to technological resources and without any monitoring, none, it has been immoral [...]. People come and stay for a year [...]. I arrive at the ward and there's nobody left whom I have trained. [...] There won't be anyone left in six months. The turnover is absurd [...] (E11).

Hence, a high turnover is observed in the nursing team; these findings are in line with another study, ${ }^{16}$ which highlighted that the turnover in nursing is linked to a macro-structural, economic and political context that is present nowadays, with privatizing characteristics.

The study highlights that a strong scrapping of the public hospital network has been occurring, evidenced through the precariousness of the work conditions, such as long work hours and shifts, outdated wages, a high activity volume. ${ }^{16}$ The following statement evidences this same situation:

the Unified Health System tries to be a universal system in a world that works according to a logic of very great individualism. So there is a series of power groups that are struggling to see who prevails, who 
wins. That shows the losses of the workers' class, and especially of nursing, with low wages and an absurd work volume [...] (E09).

Thus, the unstable bonds that permeate the profession, associated with absurd wage differences, make the workers more competitive and confront them with relationship difficulties. In addition, there is a high turnover among the workers with precarious contracts, which entails repercussions for the hospital nursing work process, for the quality of care delivery and for the workers' health. ${ }^{1}$

\section{Implications of the neoliberal model in the socioeconomic and health policies}

The fourth category contains 69 RUs, corresponding to $31.64 \%$ of the total. In this category, the loss of the labor rights a significant group of workers had conquered a long time ago stands out. This situation negatively influences these workers' quality of life, in view of the loss of sick leave, no guarantee of a Christmas bonus salary or paid vacations and, after five years, the job contract is terminated, leaving the workers without a job and without the right to financial compensation. The following statements express this analysis:

[...] in the last two decades, a flexibilization process of the labor legislation has happened, in which many gains the workers obtained in the course of decades of struggles, particularly from the 1960's, were lost or are being lost. There is a series of proposal though, in terms of integral care, universal care, welcoming, the supply of a high-quality service. But these proposals should also be provided for the workers, for them to have a minimal degree of safety at work, training, welcoming which is also necessary for these workers. I think that situation reflects a posture that goes against history [...] (E13).

[...] there are more employees hired on precarious contracts, without receiving the rights and, for example, who do not have the same rights as permanent workers. Consequently, you have two types of employees: one without [on a very low wage and without labor rights] and another on a fair wage and with labor rights [...] (E14).

As regards the implications of the neoliberal model in the socioeconomic and health policies, the losses of the labor rights in the course of decades the subjects mentioned were: paid leave, medical leave, Christmas bonus salary, weekly day-off, retirement. According to the subjects, these losses were enhanced as from the 1990's, characterized as a landmark in the transformation of the job world, in which intense transformations occurred in the labor legislation that underlies the neoliberal model. ${ }^{17}$

Thus, the Brazilian labor legislation has gone through changes - sometimes subtle, sometimes explicit - which facilitate the heterogeneity of the contractual relations between employer and employee and which minimize or extinguish labor rights. These changes take place in a socioeconomic context characterized by a high rate of unemployment in Brazil and around the world. In addition, the fragmentation and deregulation of the job market affect the Brazilian constitution and the Consolidation of Labor Laws as a new characteristic of the globalized world. ${ }^{18}$

Nevertheless, the role of the State was reduced to the non-violation of individual rights, that is, it boils down to protection against violence, theft and compliance with contracts, through the funding of military power; protection against injustice that may affect individuals; performance of works that offer advantages to society, provided that this is neither a source of profit nor competes with private entities; and preservation of the legislative, executive and judiciary power spheres. ${ }^{6}$

Thus, according to the neoliberal discourse, in the labor world, the increasing flexibility of jobs not only represents a strategy to reduce the impacts of unemployment, but is also responsible for the reduction of salaries and the loss of labor rights, making the workers more vulnerable. ${ }^{18}$ And, stigmatized by the low wages, the absence of social security and the lack of professional recognition, the precariousness culminates in an emotional wear and in threats to health and quality of life. ${ }^{1}$

\section{CONCLUSION}

As a result of the influence of the neoliberal model on the organization of hospital work, some aspects are evidenced for nursing work. According to the subjects, the management more strongly controls the hospital material, bringing about the optimization of these inputs and lower hospital spending. Another aspect that stood out was the adoption of the Standard Operating Procedures as a way to systemize the nursing care, considering that, besides helping to reduce the waste and 
high material costs, they also minimize the time spent, increase the productivity and reduce the possibility of errors and problems.

Another aspect mentioned, which revealed distinguish views, is the use of technologies. According to some subjects, the technologies facilitate the patient care process, as they evidence clinical parameters that guarantee the safety during care and permit early interventions in view of problems. Dialectically, however, they often distance the professionals from their work object - care for human beings -, thus hampering comprehensive, personalized and humanized care delivery.

In addition, as a repercussion of the neoliberal model, the great potential deterioration of the interpersonal relations is considered, as this model entails a high staff turnover and the need for the workers who stay on their job to train the new workers with precarious contracts. The continuous experience of this situation causes wear and tension in interpersonal relationships.

These research results contribute to reflections on the nurses' hospital work, in the management and care dimensions, guided by the neoliberal model and its sociopolitical and technical influences. Therefore, this study helps to deepen the analysis of the job world and the configuration of nursing work in Brazil and, based on these results, strategies can be devised to minimize the negative impacts of this production model in the work and the workers' health.

This theme should be discussed in undergraduate nursing programs so that the future nurses can understand their job contexts, with a view to building psychocognitive tools that help to transform the adverse work environments. In addition, other professionals should be involved in future research - such as the hospital managers and team heads and leaders - in order to complement the analysis and discuss other dimensions this study did not intend to investigate.

\section{REFERENCES}

1. Traesel ES, Merlo ARC. Trabalho imaterial no contexto da enfermagem hospitalar: vivências coletivas dos trabalhadores na perspectiva da Psicodinâmica do Trabalho. Rev Bras Saúde Ocup. 2011 Jan-Jun; 36(123):40- 55.

2. Antunes R. Adeus ao trabalho? Ensaios sobre as metamorfoses e a centralidade do mundo do trabalho. 14a ed. São Paulo: Cortez; 2011.
3. Góis OS, Guimarães J, Medeiros SM. Neoliberalismo e Programa Saúde da Família: a propósito do trabalho precarizado. Rev Enferm UFPE Online [online]. 2010 Mai-Jun [acesso 2013 Dez 20]; 4(Esp):1204-10. Disponível em: http:/ / www.revista. ufpe.br/revistaenfermagem/index.php/revista/ article/viewFile/1098/pdf_96

4. Ministério da Saúde (BR), Relatório Final da XIII Conferência Nacional de Saúde - Saúde e Qualidade de Vida. Brasília: MS; 2009.

5. Antunes R. Os sentidos do trabalho: ensaios sobre a afirmação e a negação do trabalho. São Paulo (SP): Boitempo; 2011.

6. Costa DO, Tambellini AT. A visibilidade dos escondidos. Physis: Rev Saúde Coletiva. 2009; 19(4):953-68.

7. Oro J, Matos E. Possibilidades e limites de organização do trabalho de enfermagem no modelo de cuidados integrais em instituição hospitalar. Texto Contexto Enferm [online]. 2014 Abr [acesso 2014 Out 20]; 8(4):974-80. Disponível em: http:// www.scielo.br/pdf/tce/v22n2/v22n2a28.pdf

8. David HMSL, Mauro MYC, Silva VG, Pinheiro MAS, Silva FH. Organização do trabalho de enfermagem na atenção básica: uma questão para a saúde do trabalhador. Texto Contexto Enferm. 2009 Abr-Jun; 18(2):206-14

9. Bardin L. Análise de conteúdo. Lisboa (PT): Edições 70; 2011.

10. Guerrero GP, Beccaria LM, Trevizan MA Procedimento operacional padrão: utilização na assistência de enfermagem em serviços hospitalares. Rev Latino-Am Enferm. 2008 Nov-Dez; 16(6):966-72.

11. Bruno MLM, Barbosa IM, Sales DS, Menezes AVB, Gomes AF, Alves MDS. Condutas de enfermagem no extravasamento de quimioterápicos antineoplásicos: Protocolo Operacional Padrão. Rev Enferm UFPE Online [online]. 2010 Mai-Jun [acesso 2013 Dez 20]; 4(esp):974-80. Disponível em: http:/ / www.revista. ufpe.br/revistaenfermagem/index.php/revista/ article/view/4319/pdf_4917

12. Cassiani SHB, Gimenes FRE, Monzani APS. O uso da tecnologia para a segurança do paciente. Rev Eletr Enf [online]. 2009 [acesso 2013 Nov 25]; 11(2):413-7. Disponível em: http://www.fen.ufg.br/revista/ v11/n2/pdf/v11n2a24.pdf

13. Silva FC, Ferreira MA. A tecnologia em saúde: uma perspectiva psicossociológica aplicada ao cuidado de enfermagem. Esc Anna Nery. 2009 Jan-Mar; 13(1):169-73.

14. Silva FC, Ferreira MA, Apostolidis T. Práticas de cuidado dos enfermeiros intensivistas face às tecnologias: análise à luz das representações sociais. Texto Contexto Enferm [online]. 2014 Abr-Jun [acesso 2014 Out 19]; 23(2):328-37. Disponível em: http://www.scielo.br/pdf/tce/v23n2/pt_01040707-tce-23-02-00328.pdf 
15. Silva FC, Ferreira MA. A dimensão da ação nas representações sociais da tecnologia do cuidado de enfermagem. Esc Anna Nery. 2011 Jan-Mar; 15(1):140-8.

16. Ferreira RES, Souza NVDO, Gonçalves FGA, Santos DM, Pôças CRMR. O trabalho de enfermagem com clientes HIV/Aids: potencialidade para o sofrimento psíquico. Rev Enferm UERJ [online]. 2013 Out- Dez [acesso 2014 Out 19]; 21(4):477- 82. Disponível em: http://www.facenf.uerj.br/v21n4/v21n4a10.pdf
17. Souza NVDO, Maurício VC, Leite, GFP, Mello $\mathrm{CV}$, Gonçalves FGA, Santos NS, et al. O cliente em situação cirúrgica e sua condição laboral: reflexões para a prática de enfermagem. Rev Enferm UERJ. 2011 Out-Dez; 19(4):632-7.

18. BaraldiS, Car MR. Flexibilização e desregulamentação laboral dos trabalhadores da área de enfermagem no Brasil: o caso Profae. Rev Latino-Am Enfermagem. 2008 Mar-Abr; 16(2):205-11. 